\title{
Ethical Values of Online Islamic Education Based on the Perspective of KH. Hasyim Asy'ari
}

\author{
Muhammad Abror Rosyidin \\ Universitas Hasyim Asy'ari, Tebuireng \\ Abror300311994@gmail.com
}

\begin{abstract}
This study aims to explain the reality of the teaching of Islamic education (PAI) through the online system during the coronavirus pandemic that affects ethical values from the point of view of the book of Adab al'Alim wa al-Muta'allim by KH. M. Hasyim Asy'ari. The focus or problems in this research are: (1) the concept of Islamic education (PAI), (2) the problems of PAI learning through an online system, (3) the ethical values of PAI learning from the perspective of the book of Adab al-Alim wa al-Muta'allim and (4) analysis of the ethical values of PAI learning through an online system based on the perspective of the book of Adab al-Alim wa al-Muta'allim. This article is based on library research. In collecting the data, the authors use the method of documentation and recording. To analyze the data, the author uses content and descriptive analysis. In this article, the author argues that according to the book of Adab al-Alim wa al-Muta'allim, online learning cannot meet the ethical standards that should be obtained through face-to-face learning. In order to address this issue, there are some recommendations: (1) at the beginning of the online lesson; the teacher can start by reading the Quran, reciting dhikr, or repeating the memorization of short verses of the Quran, or hadiths, (2) the amount and the pace of the lesson must be adjusted, (3) If it is necessary, additional learning can be provided, by a home visit with the application of strict health protocols of Covid-19.
\end{abstract}

Keywords: KH. M. Hasyim Asy'ari, Ethical Values, Islamic Education (PAI), Online Learning, Adab al-'Alim wa al-Muta'allim 


\section{Introduction}

If explored in depth, the main goal of Islamic teachings is to create an ethical society. This is at least acknowledged by two Muslim intellectual figures, namely Fazlur Rahman and M. Syafi'i Ma'arif. Fazlur Rahman stated that the central purpose of the Quran is to create a stable and living social order on earth, which is just and based on ethics. ${ }^{1}$ Meanwhile, Syafi'i Ma'arif argues that Islam places great emphasis on the need for ontological security for the development of a society and civilization in which transcendental moral principles are the main principle. ${ }^{2}$

Islamic education is the most important component of the education system in Indonesia. Because Islamic education contains moral, intellectual and spiritual education. Thus, Islamic education is an integral part of national education as an educational component in it. In Law no. 20/2003 Article 37 Paragraph 1 concerning the national education system explains that the curriculum for primary and secondary education must include, among other things, religious education. ${ }^{3}$

In his explanation it is stated that religious education is intended to shape students into human beings who believe and fear God Almighty and have noble character. Religious education is a conscious effort made by teachers to influence students in the context of forming religious people. ${ }^{4}$

Education is one of the human resource investments that are expected to changethe life of a nation for the better. As a social investment that aims to improve human resources. Of course, education that takes place in Indonesia is not only expected to succeed in transferring knowledge and values to the next generation, but also to improve the fate and quality of civilization of its people. ${ }^{5}$

In addition, education is one of the most important aspects to form a generation that is ready to replace the baton of the older generation in order to buildfuture. Therefore, education plays a role in socializing new abilities to them so that they are able to anticipate the demands of a dynamic society. ${ }^{6}$

However, looking at the reality of today's life, the Corona Virus Diseases (Covid-19) pandemic has changed the joints of human life today. The world of education is also affected. Face-to-face learning is hindered, constrained, even stagnant. Instead, the government launched distance learning, through the internet and media instruments used, such as Zoom Meeting, Google Meeting, Google Classroom, Whatsapps and others. The tools, which are then integrated

${ }^{1}$ Fazlur Rahman, Tema-tema Pokok Al-Qur'an. (Bandung: Pustaka, 1998), 56.

${ }^{2}$ M. Syafi'i Ma'arif, Membumikan Islam. (Yogyakarta: Pustaka Pelajar. 1995), 20.

${ }^{3}$ UU No. 20/2003 Pasal 37 ayat 1 tentang Sistem Pendidikan Nasional

${ }^{4}$ Zakiyah Daradjat, Metodik Khusus Pembelajaran Agama Islam, (Jakarta: Bumi Aksara, 2014), 172

${ }^{5}$ Syamsul Kurniawan, Jejak Pemikiran Tokoh Pendidikan Islam, Jogjakarta: Ar-Ruzz Media, 2011), 5.

${ }^{6}$ Muhaimin, Konsep Pendidikan Islam, (Solo: Ramadlan, 1991), 9. 
into the system in the network (online) become a substitute for the classrooms that have been built. Unfortunately, it is not possible to predict how long this will continue.

Under such conditions, ethical positions are often neglected and marginalized. The school has difficulty monitoring the learning conditions of their students. Moreover, the teacher can't freemake an evaluation of one student for learning from a far. Including ethical values, which can be difficult to obtain if online learning continues.

Topouring his thoughts on Islamic education, KH. Hasyim Asy'ari has summarized a book he wrote entitled Adab al'alim wa al-Muta'allim. The book is a book that contains the concept of education. This book was completed on Sunday, 22 Jumadil Akhir 1343 of Hijriyah. KH. Hasyim Asy'ari wrote this book based on the awareness of the need for literature that discusses ethics (adab) in seeking knowledge. According to KH. Hasyim Asy'ari seeking knowledge is a very noble religious occupation so that people who seek it must show noble ethics as well. In this context, KH. Hasyim Asy'ari seems to want that in carrying out religious activities it is accompanied by polite social behavior (al-akhlak al-karimah).

Hadratussyaikh KH. M. Hasyim Asy'ari in his book Adab al'Alim wa alMuta'allim, explains that after faith and piety, character, ethic, and morality are very important foundations in the educational process. And all of that must be owned by education personnel, both students and educators. All under the same pressure, namely morals, character, and ethics in education. Hadratussyaikh saw that education is an understanding of knowledge and the formation of good character which is full of true and perfect understanding of Islamic teachings, and is able to actualize it in everyday life. ${ }^{\text {? }}$

Hadratusssyaikh shows several texts regarding the explanation of the position of adab and which emphasizes that all religious actions, whether in the form of heart work or physical work: in the form of words or actions, are not considered in the slightest unless they are accompanied by good adab, commendable character, and noble character. Kiai Hasyim also explained that an act decorated with etiquette in this world is a sign of acceptance of that action in the hereafter. Adab is not only needed by students in the learning process, but also by teachers when teaching. ${ }^{8}$

Online learning is allegedly able to provide knowledge (transfer of knowledge) but cannot provide a complete understanding of ethics. Learning Islamic education, maybe it can provide knowledge about religious theories, but not necessarily able to provide understanding, as well as religious practices, so that it can be a guide to behaving, behaving, and socializing. If ethical values in the

\footnotetext{
${ }^{7}$ Salahuddin Wahid, Mengenal Lebih Dekat Hadratussyaikh KH. M. Hasyim Asy'ari, (Jombang: Pustaka Tebuireng, 2018), 33

${ }^{8}$ Muhammad Ishomuddin Hadziq, Irsyaadu as-Saari: Kumpulan Kitab Karya Hadratussyaikh KH. M. Hasyim Asy'ari, (Jombang: Pustaka Warisan Islam Tebuireng, 2007), 11.
} 
learning process cannot be guaranteed, then the mandate of the law regarding the implementation of religious education is increasingly difficult to achieve, namely forming people who believe and fear God Almighty and have noble character, as well as an effort that is consciously carried out by teachers. to influence students in the formation of religious people.

There are several previous articles that discuss about online learning and the book of Adab al'Alim wa al-Muta'allim. Wening Sekar Kusuma and Panggung Sutapa with the title "The Impact of Online Learning on Children's Emotional Social Behavior" in the Obsession Journal Vol. 5 Issue 2 (2021), Cecilia Engko \& Paul Usmany entitled "The Impact of the Covid-19 Pandemic on the Online Learning Process" in the Accounting Journal, Vol. 6, No. 1, 2020, and Firman entitled "The Impact of Covid-19 on Learning in Higher Education", Bioma Journal, Vol. 2, No. 1, 2020. The three articles discussed the impact of the Covid19 pandemic and online learning on the quality of learning and student morale but without discussing about Adab al'Alim wa al-Muta'allim.

Lukmanul Hakim's article entitled "The Concept of Character Education from the Perspective of KH. Hasyim Asy'ari Study of the Book of Adab al'Alim Wa al-Muta'alim" in the journal al-Munzir Vol. 11, No. 1, 2018, and Roy Bagaskara "Reorientation of Educational Thought KH. M. Hasyim Asy'Ari: Ethics in Islamic Education" in the journal Islamuna Vo. 6 No. 2 2019. The two did discuss the Adab al-Alim wa al-Muta'allim book in terms of character and ethics of education, but did not compare it with the impact of the Covid-19 pandemic and online learning.

So, from the explanation above, the researcher wants to present research that explores the implementation of online learning in PAI material from the perspective of KH. M. Hasyim Asy'ari in his book Adab al-Alim wa al-Muta'allim. For this reason, this research focuses on the concept of Islamic education (PAI) and the problems of learning PAI through an online system (on the network) and then viewed using the perspective of the book of Adab al-Alim wa al-Muta'allim. This study does not discuss the dominant positive side of online learning material for PAI, because the researchers really want to focus on the problems that the solution takes from the book as the main reference.

\section{Method}

The approach used is a philosophical approach, which is used to reason systematically and compile data based on a certain point of view (in this case the point of view used is corner historical point of view in learning). ${ }^{9}$ This type of research is library research, namely research conducted by reviewing and using

${ }^{9}$ Louis O. Katsoff dalam Yuni Irawati, "Metode Pendidikan Karakter Islami Terhadap Anak Menurut Abdullah Nasih Ulwan dalam 'Buku Pendidikan Anak Dalam Islam dan Relevansinya dengan Tujuan Pendidikan Nasional', (Skripsi tidak diterbitkan, UIN Sunan Kalijaga, 2013), 26. 
library materials, including books, encyclopedias, journals, magazines and other library sources related to the subject or problem under study as data sources. ${ }^{10}$ The main references in this research is the book of Adab al-'Alim wa al-Muta'allim.

In writing research, various types of data are needed, while the type of data that the author presents in writing this research is qualitative data in the form of literature, including data on thoughts of $\mathrm{KH} \mathrm{M}$. Hasyim Asy'ari about ethical values on Islamic Religous Education learning. The data is absorbed through reference books, and other scientific works related to this research. To collect data in this study, the authors use the method of recording. Literature research is a literature study in the form of written data that contains information and explanations as well as reflections on actual and current phenomena. ${ }^{11}$

In connection with the source of data in this study is library research, then the data required comes from sources contained in the literature. The author obtained data from many related books and books, research reports, as well as several scientific research libraries from universities. The data that was obtained was collected and presented in this article by citing it, either directly or indirectly. Because this research is based on the analysis study of thoughts of KH M. Hasyim Asy'ari about ethical values on Islamic Religous Education learning, the analysis method that the author uses is a qualitative normative method, considering the type of data, the types of data analyzed using descriptive analytical methods and deductive methods.

\section{Results and Discussion}

\section{The Concept of Learning through Online Systems}

The Covid-19 outbreak has changed and disrupted many aspects of our lives, including the economy, health, politics, socio-culture, religion, and education. In the fieldeducation, for example, Corona has closed millions of schools. UNESCO data (2020) reports that $91.3 \%$ or around 1.5 billion students worldwide cannot attend school as usual, as a result of Covid. They have to learn from home through various available media. This number includes approximately 60 million students and 4 million teachers in 565,000 schools throughout Indonesia who are experiencing similar conditions. Since the Covid pandemic, online learning is no longer an option, but a necessity.

Online is the only option to ensure learning goes on. The latest four (4) Ministerial Decrees confirm that online learning in the majority of Indonesian regions will be extended until the end of the year. Since the issuance of a circular letter on March 9, 2020 by the Minister of Education, Culture, Research and Technology, Nadiem Makarim regarding the call for Distance Learning (PJJ). This certainly adds new challenges for every education actor in Indonesia. The

${ }^{10}$ Sutrisno Hadi, Metodologi Research (Yogyakarta: Andi Offset, 1990), 9.

${ }^{11}$ Wardi Bachtiar, Metodologi: Penelitian Ilmu Dakwah, (Jakarta: Logos, 1997), 77. 
obligation to study online has added to the complexity of national education problems which, before the pandemic, were actually problematic. Among the problems of online learning in Indonesia is the large gap in public access to the availability of internet services in Indonesia (digital divide). Urban communities certainly have different levels of internet availability from villages, especially remote areas, as well as the gap between Java and outside Java. Not to mention, it is associated with the level of education and economic awareness of Indonesian families.

There are more than 40 thousand schools in Indonesia, even in the blankspot area, an area where there is no cellular network at all. In addition to the problem of internet network infrastructure that is not evenly distributed in Indonesia, the problem of online learning in Indonesia is also related to the competency divide among teachers. Quite a lot of teachers and even lecturers are not fully ready to do this online learning. A survey from the Ministry of Education and Culture (2020) also revealed that more than $76 \%$ of teachers claimed to be weak in terms of mastering digital technology for learning.

Referring to the book Adab al-Alim wa al-Muta'allim by Hadratussyaikh KH. M. Hasyim Asy'ari, studying religion will not be good if it is not based on the cultivation of morals. In fact, morals or $a d a b$ is stated to be more important than knowledge it self. So if it is deemed necessary to strive for it in this new normal era, it must still be carried out by following the health protocols issued by the government and other health institutions, such as the Indonesian Doctors Association (IDI).

Continuity of knowledge and morals is the main idea in religious education, where it is taught how to cultivate the character of an ethical, moral, and noble Islamic generation. This is reflected in religious education, as a form of tradition which essentially contains the continuous cultivation of knowledge and morals. This is an advantage of religious education that is not owned by other education providers. When face-to-face learning cannot be carried out, of course, religious teachers find it difficult to realize their superiority, in fact they are further away from their initial ideals.

In addition to the problems above, there is another problem that is very contrary to the ideals of religious education, namely the supervision of the teaching and learning process. School control of children's development becomes very difficult, so it seems like it is. One form of miscontrol in this method is the unpreparedness in providing spaces for ethical values in the process. The ethics of learning become disorganized and difficult to know the facts.

This problem has an impact on learning Islamic education which is not optimal, where not all parents can accompany their children properly. The function of control that passes from school to parents makes it difficult to supervise due to various factors. First, internal factors that can be caused by parents who are busy working, parents' educational background is inadequate, or 
the family's economic condition is insufficient. Meanwhile, it can also be from external factors, namely the environmental conditions that overshadow the community and technological developments such as games, social media, and other entertainment applications.

Even when learning online, it is known that there are many cases of students not acting ethically, for example studying while sleeping, playing games and social media during learning, and other similar cases. For this reason, it is necessary to review the ethical values of the online system in PAI learning, which is actually a learning system that upholds ethical, moral, and moral values. In other words, today's online learning system is far from worthy of replacing the face-to-face system in schools.

Some negative things began to emerge when applying online in learning. Nadiem is aware that there are at least 3 (three) negative impacts of prolonged PJJ. First, the risk of an increase in the dropout rate. They prefer to work to help parents who are economically affected by the pandemic. It could also be that with the implementation of PJJ, they do not feel the presence of the school as a place for teaching and learning. Second, the risk of decreasing learning achievement. The socio-economic quality of the Indonesian people also influences the learning achievement. The gap cannot be controlled because the distance between education providers, educators, and students is far apart. Third, there is a risk of violence outside the school (home) that is not detected by the school. There are other effects that can arise, ${ }^{12}$

Moral problems also haunt. There are several things that happen when the PJJ process is implemented and it hurts the morale of the nation's generation. In Balikpapan, two students were recorded doing lewd acts during online learning on August 13, 2021. They were doing online activities together at home without their parents. They forgot to turn off the camera while doing scenes like husband and wife. In October 2020, in Kupang, East Nusa Tenggara, a student was accused of committing lewd acts during the online lecture process. These two cases are just examples recorded by digital media.

Online learning also results in changes in children's attitudes. This attitude can be in the form of four things, namely (1) a cheerful child turns moody and looks unattractive, (2) the child begins to hurt himself, (3) the appetite suddenly decreases and (4) withdraws from family interactions. Children who experience symptoms of such psychological disorders, may have to be directed to use the services of a psychologist to help restore attitudes. There is one problem that is almost the same, namely the atmosphere created by online and offline learning

12 Barratul Taqiyah Rafie, Tiga Akibat bila Pembelajaran Jarak Jauh (PJJ) Terlalu Lama, https://nasional.kontan.co.id/news/tiga-dampak-negatif-bila-pembelajaran-jarak-jauh-pjjterlalu-lama?page=2, (diakses pada 26 Agustus 2021 pukul 13.57 WIB). 
which is very different. This can result in decreased motivation and enthusiasm for learning. ${ }^{13}$

Learning during the pandemic also causes several other problems. First, the crisis of religious and social values. In this case, it is closely related to attitude and ethics. Second, the credibility gap, where the classification of others is seen from the ability to accommodate learning instruments, not the results and the learning process itself. Third, the lack of idealism towards the achievement of education. Efforts are made as necessary, or just a formality. Fourth, the lack of sensitivity to the future. The vulnerable generation experiences acute pessimism, where their future is viewed with a shorter lens, namely being able to get out of the pandemic period that disrupts their socio-economic situation. ${ }^{14}$

At an early age, the impact of being online is even more pronounced. When learning takes place, children tend not to be cooperative, meaning that they do not want to carry out tasks, homework, and so on. In addition, children's development also becomes less, where they do not socialize well as if learning is done via offline. These two things cause children to become bored, and sometimes cause uncontrolled emotions. They miss their teachers, school, and friends. At home, because children are difficult to manage, parents are also sometimes carried away by emotions, resulting in verbal violence, where early childhood gets harsh treatment, threats, pressure, intimidation, and so on, which can worsen the child's situation. ${ }^{15}$ This change in attitude affects the formation of children's character in the future.

As a result of this unpreparedness, in the early days of the pandemic, many teachers, instead of doing online learning, gave students piles of assignments. Survey from the Indonesian Child Protection Commission (KPAI) received 213 distance learning (PJJ) complaints, over a period of time three weeks, starting from March 16 to April 9, 2020. The majority of complaints are related to the severity of assignments given by teachers to students. Majority teachers do more online learning by giving assignments to students through several platforms such as whatsapp in the early days of online learning obligations. Even a survey from the same institution also reported that $58.8 \%$ of teachers surveyed admitted to giving

13 Veramyta Maria Flora Babang, Permasalahan Belajar Online Selama Pandemi Covid-19, dalam "Adabtasi Kebiasaan Baru Masyarakat Indonesia pada Era Pandemi Covid-19: Tinjauan Dari Berbagai Disiplin Ilmu”, (Tulungagung: Akademia Pustaka, 2020), 38-39.

14 Tuti Nuriyati, Problematika Pendidikan Islam Pada Masa Pandemi, dalam "Adabtasi Kebiasaan Baru Masyarakat Indonesia pada Era Pandemi Covid-19: Tinjauan Dari Berbagai Disiplin Ilmu", (Tulungagung: Akademia Pustaka, 2020), 48-49.

15 Wening Sekar Kusuma dan Panggung Sutapa, Dampak Pembalajaran Daring terhadap Prilaku Sosial Emosional Anak, Jurnal Obsesi Vol. 5 Issue 2 (2021), (Kampar: FIP Universitas Pahlawan Tuanku Tambusai), 1638-1641. 
the same assignments to all students regardless of the socio-economic and personal conditions of students. ${ }^{16}$

Actually it is not only felt by school students, but also students at the college level. Many obstacles are felt during the online learning process. Lecturers feel that the learning process has been effective but has not been maximized because they cannot meet face-to-face with their students so there are doubts whether the material provided is conveyed or not. Students also feel burdened with limited data quotas and network problems that hinder the lecture process. ${ }^{17}$

Unlike students in elementary and high school, at the tertiary level, the call for students to study from home during the Covid-19 pandemic has surprisingly been able to increase student learning independence. The online learning environment gives students the freedom to plan and implement their learning. The limited interaction with lecturers and with peers makes students more independent in managing study time, doing and collecting assignments, as well as looking for learning resources other than teaching materials provided by lecturers to support their understanding of the material being taught. ${ }^{18}$

\section{Concept of Ethical Values (Akhlak) in PAI Learning, Perspective KH. M. Hasyim Asy'ari}

Hadratussyaikh KH. M. Hasyim Asy'ari did not explain in detail the meaning of $a d a b$ and morals, both the literal and the literal meanings. The author sees Kiai Hasyim doesn't want to beat around the bush and get straight to the point. Judging from the purpose of writing the book Adab al'Alim wa al-Muta'allim, which is to provide guidelines, a kind of pocket book for students. Pocket book is certainly not too thick and substantial.

Imam Ghazali defines morality in his book Ihya 'Ulum ad-Din, is a temperament (character) that stays strong in a person's soul and is the source of the emergence of certain actions from himself, easily and lightly, without the need for thought or or planning beforehand. ${ }^{19}$ Meanwhile, according to Ibrahim Anis, morality is a trait that is embedded in the soul, which gives birth to various actions, good or bad, without the need for thought and consideration. ${ }^{20}$

Another term in Indonesian for morality usually uses the word ethics. However, both have substantial differences, namely the concept of morality comes

\footnotetext{
16Afrianto Daud, "Pembelajaran Daring dengan 3M (Media, Metode, dan Materi), https://riaupos.jawapos.com/citizen-jurnalis/13/07/2020/234850/pembelajaran-daringdan-3-m-media-metode-dan-materi.html, (diakses pada 12 Agustus, pukul 13.38 WIB).

${ }^{17}$ Cecilia Engko \& Paul Usmany, Dampak Pandemi Covid-19 dalam terhadap Proses Pembelajaran Online, Jurnal Akuntansi, Vol. 6, No. 1, 2020, (Ambon: Universitas Pattimura), 37

${ }^{18}$ Firman, Dampak Covid-19 terhadap Pembelajaran di Perguruan Tinggi, Jurnal Bioma, Vol. 2, No. 1, 2020, (Semarang: Fak. Matematika Universitas PGRI), 19.

${ }^{19}$ Muhammad al Ghazali, Ibya Ulumuddin Jilid III, (Beirut: Dar al Fikr, 2008), 57

${ }^{20}$ Ibrahim Anis, Al Mu'jam al Wasith (Kairo: Maktabah as Syuruk ad Dauliyyah, 2004), 252
} 


\section{Abror Rosyidin}

from a religious view of human behavior, while the concept of ethics comes from a view of human behavior in a philosophical perspective. ${ }^{21}$

The word $a d a b$ in the Arabic dictionary means politeness, ${ }^{22}$ namely giving rights to everything and time, and knowing what is the right of oneself and the right of Allah SWT. noble behavior or spiritual manners in the Sufi way and perfection in words and deeds. The science of Sufism is based on adab that ranges from correct behavior in accordance with the Shari'a to continuous spiritual manners to Allah SWT. ${ }^{23}$

So we can understand that here, morality is more about nature, while adab is attitude and behavior. Morals still have to be further divided into al-karimah morals (noble morals) and al-madzmumah morals (bad morals), while adab is definitely an order of attitudes and behavior that is considered good by a community.

For this reason, what is meant by moral competence and etiquette of teachers in Islamic education, namely the ability and skills of teachers in using good ethics, morals, attitudes and behavior, in the implementation of Islamic education as a conscious effort in encouraging Muslim students to understand science with values. the values and teachings of the noble Islamic religion.

Hadratussyaikh KH. M. Hasyim Asy'ari sees the base of the educational pyramid is piety to Allah SWT that the intention of the process of transforming knowledge is to gain the pleasure of Allah SWT. Including teachers. In the process of teaching a teacher, Hadratussyaikh said:

"First, always feel supervised by Allah SWT when alone or with other people. Second, always fear Allah SWT in every movement, silence, speech and deed, because knowledge, wisdom and fear are trusts entrusted to him so that if they are not guarded, they are treason. ${ }^{24}$

Meanwhile, Kiai Hasyim said that the pinnacle of seeking knowledge is its practice. This is clearly stated in the book of Adab al-'Alim wa al-Muta'allim:

21 Hamdani Hamid dan Beni Ahmad Saebani, Pendidikan Karakter Islam, (Bandung, Pustaka Setia, 2013), 49

${ }^{22}$ Ahmad Warson Munawwir, Kamus Arab-Indonesia, (Surabaya: Pustaka Progressif, 1997), 13

${ }^{23}$ Totok Jumantoro dan Samsul Munir Amin, Kamus Ilmu Tasawuf, (Wonosobo: Amzah, 2005), 3

${ }^{24}$ Muhammad Ishomuddin Hadriq, Irsyaadu as-Saari: Kumpulan Kitab Karya Hadratussyaikh KH. M. Hasyim Asy'ari, (Jombang: Pustaka Warisan Islam Tebuireng, 2007), 5 
"The purpose of knowledge is to practice it because charity is the fruit of knowledge, makes life useful, and can be a provision in the hereafter. So whoever gains it wins and whoever loses it loses." ${ }^{25}$

PAI is a complete reflection of a collection of teachings consisting of fiqh (law), worship, history, Quran-Hadith, and morals. Morals as a part of PAI, actually join be an indicator of the success of educating students. Before talking about the ethical values of students in the learning process, we need to look at Kiai Hasyim in the book mentioning the manners of students towards their teachers consisting of twelve points, namely:

First, students should consider what kind of teacher is in front of them teaching science. The reflection is seen from competencehis skillsin teaching, compassion, a good image, the ability to maintain self-purity, and the ability to teach and understand good. Here, students are required not only to receive lessons, but also to have the right to assess their teachers, in terms of personal and social competence.

Second, ensure that the teacher who is teaching knowledge to him, is a PAI teacher who understands religious matters and the Shari'a. These teachers are known to learn from their teachers, and gain knowledge from research and scientific dialogue with experts or experts. Kiai Hasyim criticize teachers who were born from sheets of book paper and never learned directly from expert teachers.

Third, obedient to the teacher in many ways and not against his opinions and rules. The student and the teacher are in the same position as the patient and the expert doctor. Here, Kiai Hasyim emphasizes optional obedience. It means obeying the good things, not the ones that lead to the bad. Fourth, look at the teacher with respect and reverence. Students look at the teacher with full confidence that the teacher candeliver it at the door of abundant knowledge. Kiai Hasyim encourages children who are in the learning process to be at the level of confidence, and minimize doubts.

Fifth, know and understand the rights of teachers and respect them. Pray for him, whether he is alive or dead. Even according to Kiai Hasyim, respectit does not stop with the teacher, but continues to his family, descendants, and loved ones. Sixth, be patient for the unkindness and lack of good behavior that arises from the teacher. Even when students face teachers who scold them, they should be able to introspect themselves, whether there is something wrong in their behavior. If there is a misunderstanding between students and teachers, it is necessary to have tabayun so that things don't happen that result in worse.

Seventh, ask permission if you want to meet the teacher in the learning assembly. Order of permission etiquettemeet teacher explained by Kiai Hasyim in detail as follows:

25Ibid, 13-14 
"If you have given permission (such as greeting) you want to meet once and the teacher knows it but doesn't allow it, then the student must go and not repeat the request for permission. If in doubt whether the teacher hears the request for permission to meet from the student or not, then it is permissible to repeat it a maximum of three times or by knocking on the door three times but with a reasonable beat full of etiquette, such as by using fingernails and then gradually with fingers. When the teacher hasallow enter and students who want to meet a lot then the older one enters first while saying greetings then followed by the others in order of age while saying greetings in turn. One should also meet the teacher in a good appearance, clean and pure body and clothes after trimming the nails and removing unpleasant body odors. 26

Eighth, Kiai Hasyim explained the manners of students when they were in the assembly together the teacher:

"If the student sits in front of the teacher, he should sit with good etiquette, such as sitting cross-legged on his knees or sitting tasyahud without puthands on the thighs, or sitting cross-legged with a sense of humility, low self-esteem, calm and solemn. Students are not allowed to look away except in an emergency. Instead, he must face his teacher perfectly while watching, listening carefully, then daydreaming about what he is saying so that the teacher does not have to repeat it.his wordsagain. Do not let students not pay attention by looking to the right to the left or up unnecessarily, especially when the teacher is explaining, or not paying attention because they are busy seeing the sudden noise they hear.

Ninth, students do their best to say good things to the teacher. Kiai Hasyim even used an example ofsaywhich should not be said for example, "Why?", "I do not accept" (with the teacher's answer), "Who said that", "Where is the place" (teacher's explanation). If there is a need for a deeper explanation, students must ask permission with a kind and polite sentence, or ask in another forum or meet in person specifically to ask questions.

Tenth, when students hear the teacher mention a science, explain a useful information, tell a story, or discuss asyir, but he has understood it before, he must still listen carefully, take advantage, thirst (for knowledge) and rejoice as if he had

${ }^{26}$ More can be seen in the book Adab al-'alim wa al-Muta' allim 
never heard. It teaches them about the importance of appreciating knowledge and preventing pretending to know.

Eleventh, it's still a matter of avoiding a know-it-all attitude. Students should not precede or coincide with the teacher in explaining a problem or in answering questions. It didn't appear that he was aware of it either and didn't interrupt any of the teacher's words. Patience in preventing the desire for superiority of one student over another or over the teacher, in the classroom is the key to this point.

Twelfth, there are guidelines for etiquette to hand something over to the teacher. Kiai Hasyim said:

"When the teacher gives something, the student must accept it with the right hand. If a student gives something to the teacher, such as a paper containing readings concerning Islamic legal fatwas, stories, sharia knowledge or anything written, the student should spread the paper first, then hand it over to the teacher in an unfolded state, unless the teacher orders it. If the item that the student will give to the teacher is a book, the student mustdeliverthe book is in a position ready to be opened and read so that the teacher does not need to correct the position of the book. If the reading of the book has reached a certain material, then the page containing the material must be opened and students indicate which reading should be delivered. Never throw anything at the teacher such as a book, paper or whatever."27

Only after knowing the manners of students to their teachers, we try to understand how Kiai Hasyim gives advice to students about etiquette when in class (science council). There are thirteen kinds of points.

First, Kiai Hasyim explained several fields of knowledge that must be included in religious lessons that must be studied by students, namely the belief about the essence of Allah, the belief about the attributes of Allah, Islamic law, knowledge about al-ahwal wa al-maqomat (the circumstances and levels as in the science of Sufism), as well as various tricks and engineering passions and other related matters.

Second, at the next stage, students begin to have to study the Quran in order to strengthen the fardhul ain sciences (mentioned in the first point) that they have learned. Studying the Quran here can be interpretation or other sciences needed to understand it. Then in order, there are Hadith, Hadith Science, Fiqh Proposal, Usuluddin (telology/creed science), Nahwu and Shorof.

Third, students should not focus too much on the khilafiyah of the opinions of the scholars in the learning crew. This means that the focus is on content rather than the ijtihad process of the experts. It aims so that students are not confused and surprised. Fourth, students should correct the truth (tashih) of the reading material, before memorizing it, to the teacher or other qualified person. At this

\footnotetext{
${ }^{27}$ Muhammad Hasyim Asy'ari, Adab al'Alim wa al-Muta'allim, (Jombang: Pustaka Warisan Islam Tebuireng), 29-42.
} 
point the religious teacher provides materials that are rote, and that is needed. For example, prayers, prayer readings, worship intentions, memorization of short surah of the Quran etc.

Fifth, students as soon as possible hear and learn science, especially hadith and do not ignore it or the sciences related to it, also pay attention to the sanad, law, faidah, language, and history. Sixth, when the student has received an explanation from one level of knowledge, then he moves to the next level with a wider explanation.

Seventh, in addition to closely following the learning in class, you can also participate in the science assembly held by the teacher in another place. This means that this point may include additional classes to increase understanding of the lesson. Eighth, when he comes to an additional class with his teacher, he should say hello in a loud voice that can be clearly heard by all present, both when he comes and when he leaves.

Ninth, not ashamed to ask something that feels complicated and not ashamed to ask for an explanation of things that are not understood. Of course he did it gently, politely and pay attention to ethics in asking. Students are not allowed to ask something that is not in their place unless it is necessary or the teacher allows it. It means asking something outside the theme.

Tenth, in additional classes, perhaps there is a one-by-one learning process or in a pesantren there is a bandongan method, one by one goes forward to mentashih knowledge, then you have to wait your turn, you may not take other students, except with the willingness of the person concerned. Eleventh, students sit in front of the teacher according to the etiquette that has been explained in detail in the chapter on etiquette to the teacher. He should bring his own books and stationery. The question of etiquette towards books and starting learning is explained by Kiai Hasyim:

"Do not put the book that is being read on the floor in an open state, but the student must hold it. Do not read books except after asking permission from the teacher. Not reading the book when the teacher is busy, bored, angry, difficult and so on. If the teacher allows the student to read the book, then the student first reads ta'awudz, then basmalah, tahmid and sholawat along with greetings to the Prophet Muhammad, his family and friends. Then pray for the teacher, his parents, the masyakhs, himself and all Muslims. And ask Allah for mercy for the author of the book to be read."

Twelfth, students should focus on one lesson first, so as not to let it go to waste, focus on one discipline so as not to move on to study other disciplines before the first one is properly mastered. Regarding seating, students should not 
move from place to place unless there is an urgent need, because it is considered to complicate matters, occupy the mind and waste time.

Thirteenth, students motivate each other, to try to gain knowledge and provide information to each other about the science assembly, advise each other so as not to forget to study, help each other in matters of living expenses (including education costs), and hold group studies with a joint learning system, so that his mind will be brighter, his knowledge will be blessed and his reward will increase. That means mutual cooperation in talab al-ilmi, so as not to pride themselves on each other above others. ${ }^{28}$

28Ibid, 43-54 


\section{Analysis/ Discussion}

From the data above, we can analyze the meeting between the ethical values conveyed by KH. M. Hasyim Asy'ari and the implementation of PJJ or online learning due to the Covid-19 pandemic. We discuss one by one. First, students should consider what kind of teacher is in front of them teaching science. Second, ensure that the teacher who is teaching him knowledge is an Islamic Education teacher who understands religion and Shari'a. In these two points, of course, online learning cannot be done. Students cannot do quality control on their teachers. Especially choosing. Apart from the fact that teachers have been determined by the system, it is also because they cannot meet face-to-face directly. Especially for students of the generation of 2020 or 2021 who have not had time to get to know the teacher in depth.

Third, obedient to the teacher in many ways and not against his opinions and rules. The student and the teacher are in the same position as the patient and the expert doctor. Fourth, look at the teacher with respect and reverence. The online system is known to contain difficulties in controlling students, including controlling their obedience and respect for teachers. When the teacher explained the lesson, some of them turned off the camera and left the lesson for other activities.

Fifth, know and understand the rights of teachers and respect them. Similar to the previous two points, indicators of the achievement of students' morals in fulfilling the rights of teachers and carrying out their obligations cannot be measured because of the intensity of meetings that almost do not occur. Sixth, be patient for the unkindness and lack of good behavior that arises from the teacher. Bored with the teacher's lessons alone, can make them leave the online space. Moreover, they are asked to be patient to be unfriendly to the teacher when reprimanding them.

Seventh, ask permission if you want to meet the teacher in the learning assembly. Eighth, Kiai Hasyim explained the manners of students when they were in the assembly together the teacher. Of course, these two points cannot be controlled as well, whether they can happen or not. Apart from not meeting physically, permission to go out and enter the online room only, cannot be controlled. Then they can easily turn off the camera and do other activities, without the need for teacher permission. Then enter without the teacher knowing.

Ninth, students do their best to say good things to the teacher. Maybe it's this point that allows it to be controlled. The teacher can ask them to express their opinion on a problem, and then they answer. From there, teachers can assess their level of communication skills and abilities with their teachers. Or the teacher can ask them to discuss in the online room, and observe how they discuss. It is still possible to be monitored. 
Tenth, listen to the teacher's explanation carefully and don't pretend to know. Eleventh, students should not precede or coincide with the teacher in explaining a problem or in answering questions. They are overactive in speaking, even when the teacher explains, they can follow the lesson from beginning to end carefully, which is a good achievement. It is already a good indicator of achievement in online learning.

twelfth, Kiai Hasyim gave guidance on how to hand over something to the teacher. Of course this cannot be done physically. However, it can be applied through providing feedback on the teacher's explanation by expressing gratitude or positive emoticons, asking questions in a kind and polite manner, or by provoking them to give a positive response to the quality of the teacher's explanation. That is if the teacher can master the material and can handle the class well.

For the thirteen points of etiquette of students when they are in the science assembly, we analyze them thoroughly directly. At the beginning of the online lesson, the teacher can start by reading the Quran, praying, dhikr, or repeating the memorization of short surah of the Quran, or hadiths. This helps them stimulate their religious abilities. Only then were they invited to focus on following the lessons referred to in the schedule. This can accommodate the first to fifth points in the adab in the learning that Kiai Hasyim proclaims, although it is not fully fulfilled.

Because online is very limited, the level of chapters in the lessons delivered must also be adjusted. It must be carried out slowly, because if there is too much material it will cause boredom. If necessary, additional learning is held, to make up for the shortage online, you can study in groups according to the zoning where the students live or study with the teacher closest to where they live. Some schools have also implemented home visits (studying at the home of one of the students) followed by several other students who are in the same area/zone with the owner of the house. Of course, it is implemented with strict health protocols and not too many participants.

The existence of home visits or study groups accompanied by one of the teachers, can also be used to answer questions that cannot be covered online, which are complicated and difficult. In that meeting, the teacher can control the achievement of students to the extent that they understand the material presented online. The benefits are even greater, PAI lessons can also function properly, namely controlling ethics, morals, etiquette, attitudes and behavior of students face-to-face, even in limited time and conditions. At least it can reduce resistance to uncontrolled application of ethical values in online learning.

In addition, students can focus on the lesson, not divided by other activities. They can also motivate each other, help each other solve problems, do assignments, so that the achievement index does not experience prominent differentiation. And that is what is meant by ethical values in PAI learning, where religious lessons are not only focused on cognitive formalities, but also 


\section{Abror Rosyidin}

internalization of values into the daily activities of students. As a result of this pandemic and PJJ, of course it cannot be as much as face-to-face, but at least there are efforts to reduce the risk of a drastic decline in morals and ethics due to uncontrolled learning. Qoidah figh, "ma la yudraku kulluhu la yutraku kulluhu", it's mean, if there are programs, activitie, hopes, and targets cannot be achieved $100 \%$. no need to have to leave it $100 \%$ either. That is, even though it cannot be maximized, efforts must be made to the maximum extent possible in order to reduce the greatest risk.

\section{Conclusion}

Islamic education is based on three main sources, namely the Quran, Sunnah (Hadith) and Ijtihad. The method used in PAI learning also varies, it can be by exemplary, example, motivation, question and answer methods or also telling stories. The purpose of Islamic education is to foster awareness of human beings themselves and of the social system that existsIslamic. His attitude and sense of social responsibility, also towards His created nature and awareness to develop and manage this nature for the benefit and welfare of mankind.

The ethical values of students conveyed by Kiai Hasyim in the study of religious knowledge consist of two chapters, namely the manners of students to the teacher and the manners of students in the classroom (science assembly). There are 12 points of etiquette between students and teachers. While the etiquette of students in the PAI class there are thirteen kinds of points. Those points can be read in his book in more detail.

Some of the problems caused by online PAI learning, namely (1) inhibiting the internalization of religious values, and tending to be formalities, (2) competency gaps among teachers and students due to external and internal factors, (3) difficulty in carrying outsupervision of the teaching and learning process, (4) when online, many students feel bored, leave online without permission to do other activities, as well as some negative things recorded by cameras that tarnish the world of education, (5) decreased learning achievement, ( 6) lead to changes in attitude in early childhood to be moody and look unattractive, start to hurt themselves, suddenly decrease appetite, and withdraw from family interactions, (7) lessons are only measured from assignments, where teachers tend to prefer giving assignments rather than explaining the material.

Kiai Hasyim's points above are indeed difficult to be applied optimally to control students' ethical values with online learning. So need there is a solution taken from those points. (1) At the beginning of the online lesson, the teacher can start by reading the Quran, praying, dhikr, or repeating the memorization of short surah of the Quran, or hadiths, (2) the level of chapters in the lessons delivered must also undergo adjustments and be carried out slowly, (3) If necessary, additional learning is held, to fill online deficiencies, can study groups according 
to the zoning of the student's residences or study with teachers who closest to their place of residence (homevisit system) with the implementation of health protocols.

Benefits of this home visit, (1) answer questions that cannot be covered online, which are complex and difficult. (2) teachers can control the achievement of students to what extent they understand the material delivered online, (3) PAI lessons can also work as It should be, namely controlling ethics, morals, etiquette, attitudes and behavior of students face to face, even in limited time and conditions, (4) students can focus on the lesson, not divided by other activities, (5) students can motivate each other, help solve problems, and carry out a task.

\section{References}

Al-Ghazali. 2008. Ihya Ulumuddin Jilid III. Beirut: Dar al Fikr.

Anis, Ibrahim. 2004. Al-Mu'jam Al-Wasith. Kairo: Maktabah as Syuruk ad Dauliyyah.

Ashraf, Ali. 1996. Horison Baru Pendidikan Islam. Jakarta. Putaka Firdaus.

Asy'ari, Muhammad Hasyim. tth. Adab al'Alim wa al-Muta'allim. Jombang: Pustaka Warisan Islam Tebuireng.

Azwar, Saifuddin. 2004. Metodologi Penelitian. Yogyakarta : Pustaka Pelajar Offset.

Babang, Veramyta Maria Flora. 2020. Permasalahan Belajar Online Selama Pandemi Covid-19, dalam "Adabtasi Kebiasaan Baru Masyarakat Indonesia pada Era Pandemi Covid-19: Tinjauan Dari Berbagai Disiplin Ilmu”. Tulungagung: Akademia Pustaka.

Bachtiar, Wardi. 1997. Metodologi: Penelitian Ilmu Dakwah. Jakarta: Logos.

Daradjat, Zakiyah. 2014. Metodik Khusus Pembelajaran Agama Islam. Jakarta: Bumi Aksara.

Daud, Afrianto. 2020. "Pembelajaran Daring dengan 3M (Media, Metode, dan Materi)" https://riaupos.jawapos.com/citizenjurnalis/13/07/2020/234850/pembelajaran-daring-dan-3-m-media-metode dan-materi.html. Diakses pada 12 September 2020.

Departemen Pendidikan dan Kebudayaan. 1991. Kamus Besar Bahasa Indonesia. Jakarta: Balai Pustaka.

Engko, Cecilia \& Paul Usmany. 2020. Dampak Pandemi Covid-19 dalam terhadap Proses Pembelajaran Online. Jurnal Akuntansi. Vol. 6. No. 1. Ambon: Universitas Pattimura.

Firman. 2020. Dampak Covid-19 terhadap Pembelajaran di Perguruan Tinggi. Jurnal Bioma, Vol. 2. No. 1. Semarang: Fak. Matematika Universitas PGRI.

Hadi, Sutrisno. 1990. Metodologi Research. Yogyakarta: Andi Offset.

Hadziq, Muhammad Ishomuddin, 2007. Irsyaadu as-Saari: Kumpulan Kitab Karya Hadratussyaikh KH. M. Hasyim Asy'ari. Jombang: Pustaka Warisan Islam Tebuireng. 
Hamalik, Oemar. 2014. Proses Belajar Mengajar. Jakarta: Bumi Aksara.

Hamid, Hamdani \& Beni Ahmad Saebani. 2013. Pendidikan Karakter Islam. Bandung, Pustaka Setia.

Harnani, Sri. 2020. "Efektifitas Pembelajaran Daring di Masa Pandemi Covid-19" https://bdkjakarta.kemenag.go.id/berita/efektivitas-pembelajaran-daringdi-masa-pandemi-covid-19. Diakses pada 11 September 2020.

Jumantoro, Totok \& Samsul Munir Amin. 2005. Kamus Ilmu Tasawuf. Wonosobo: Amzah.

Katsoff, Louis O. dalam Yuni Irawati. 2013. "Metode Pendidikan Karakter Islami Terhadap Anak Menurut Abdullah Nasih Ulwan" dalam Buku Pendidikan Anak Dalam Islam dan Relevansinya dengan Tujuan Pendidikan Nasional". Skripsi. Yogyakarta: UIN Sunan Kalijaga.

Kurniawan, Syamsul. 2011. Jejak Pemikiran Tokoh Pendidikan Islam. Jogjakarta: ArRuzz Media.

Kusuma, Wening Sekar \& Panggung Sutapa. 2021. Dampak Pembalajaran Daring terhadap Prilaku Sosial Emosional Anak. Jurnal Obsesi Vol. 5 Issue 2. Kampar: FIP Universitas Pahlawan Tuanku Tambusai.

Majid, Abdul \& Dian Andayani. 2006. Pendidikan Agama Islam Berbasis kompetensi, Konsep dan Implementasi Kurikulum 2004. Bandung: Ramaja Rosdakarya.

Ma'arif, M. Syafi'i. 1995. Membumikan Islam. Yogyakarta: Pustaka Pelajar.

Misrawi, Zuhairi. 2010. Hadratussyaikh Hasim Asy'ari, Moderasi, Keumatan dan Kebangsaan. Jakarta: PT Kompas Media Nusantara.

Moleong, Lexy. 1996. Metodologi penelitian Kualitatif. Bandung: Rosdakarya.

Mujib, A Dkk. 2004. Entelektualisme Pesantren. Jakarta. PT. Diva Pustaka

Muhaimin. 1991. Konsep Pendidikan Islam. Solo: Ramadlan.

Munawwir, Ahmad Warson. 1997. Kamus Arab-Indonesia. Surabaya: Pustaka Progressif.

Nashir, Header. 1997. Agama dan Krisis Kemiskinan Modern. Yogyakarta: Pustaka Pelajar.

Nuriyati, Tuti. 2020. Problematika Pendidikan Islam Pada Masa Pandemi, dalam "Adabtasi Kebiasaan Baru Masyarakat Indonesia pada Era Pandemi Covid19: Tinjauan Dari Berbagai Disiplin Ilmu”. Tulungagung: Akademia Pustaka.

Poerwardarminta. 1991. Kamus Besar Bahasa Indonesia. Jakarta: Balai Pustaka.

Rafie, Barratul Taqiyah. Tiga Akibat bila Pembelajaran Jarak Jauh (PJJ) Terlalu Lama, https://nasional.kontan.co.id/news/tiga-dampak-negatif-bila-pembelajaranjarak-jauh-pjj-terlalu-lama?page=2. Diakses pada 26 Agustus 2021.

Rahman Fazlur. 1998. Tema-tema Pokok Al-Qur'an. Bandung: Pustaka.

Sugiyono. 2009. Metode Penelitian Kuantitatif dan Kualitatif Dan R EF D. Bandung: Alfabetha.

Thoha, M. Chabib. 1996. Kapita Selekta Pendidikan Islam. Yogyakarta: Pustaka Pelajar. 
Umar Husein. 2002. Metode Riset Komunikasi Organisasi: Sebuah pendekatan Kuantitatif Dilengkapi Dengan Contoh Proposal dan Hasil Riset Komunikasi Organisasi. Jakarta: Gramedia Pustaka Uatama.

Wahid, Salahuddin. 2018. Mengenal Lebih Dekat Hadratussyaikh KH. M. Hasyim Asy'ari. Jombang: Pustaka Tebuireng.

Yasin, Mubarok \& Fathurrahman Karyadi. 2011. Profil Pesantren Tebuireng. Jombang: Pustaka Tebuireng.

Zuhairini. 2004. Metodologi Pembelajaran Pendidikan Agama Islam. Malang: UIN Press. 